\title{
Effect of Ethanol on Mouse Brain Cell
}

\author{
Hyung Seok Jang \\ Department of Pathology, Hanyang University Medical Center, Seoul 133-792, Korea
}

\begin{abstract}
Ethanol has long been implicated in triggering apoptotic neurodegeneration. Alcohol also may indirectly harm the fetus by imparing the mother's physiology. We examined the effects of ethanol on immature brain of mice. Three-weeks-old female ICR strain mice daily intraperitoneally injected with ethanol at the concentration of 4 and $20 \%$ in saline for 0, 6, and 24 hours and 1 and 4 weeks. The mice were weighted and sacrificed, and the brains were ectomized for the present histological, immunohistochemical and TUNEL assays. Based on the histologic hematoxylin and eosin stain, immunohistochemical expression of glutamate receptor protein and neuronal cell adhesion molecule (NCAM) were evaluated. The cerebral cortex of the ethanol-treated group showed few typical symptoms of apoptosis such as chromosome condensation and disintegration of the cell bodies. TUNEL staining revealed DNA fragmentation in the 6 and 24 hours. This results demonstrated that acute ethanol administration causes neuronal cell death. I found that either glutamate receptor inhibition or activation could induce cerebellar degeneration as ethanol effect. Neuronal death also can be induced by excess activity of certain neurotransmitter, including glutamate. Neurons must establish cell-to-cell contact during growth and development in order to survive, migrate to their final destination, and develop appropriate connections with neighboring cell. Purkinje cell in cerebellar are especially vulnerable to the cell death and degeneration. After ethanol treatment in cerebellar, NCAM had decreased by 4 weeks. This result suggest that apoptosis seems to be involved in the slow elimination of neuron and cerebellar degeneration.
\end{abstract}

Keywords: Apoptosis, Brain, Ethanol, Glutamate, TUNEL

This is an Open Access article distributed under the terms of the Creative Commons Attribution Non-Commercial License (http://creativecommons.org/licenses/by-nc/3.0) which permits unrestricted non-commercial use, distribution, and reproduction in any medium, provided the original work is properly cited

Copyright @ 2015 The Korean Society for Clinical Laboratory Science. All rights reserved.
Corresponding author: Hyung Seok Jang Department of Pathology, Hanyang University Medical Center, Seoul 133-792, Korea Tel: 82-2-2290-8898

E-mail: himylife@hanmail.net

Received: March 16, 2015

Revised: March 23, 2015

Accepted: March 24, 2015

\section{서 론}

안전한 알코올 섭취량에 대한 기준은 알코올에 대한 인식과 관 심이 증가함에 따라 점차 낮아지는 경향이 있다(Son, 2005). 우리 나라에서도 점차 여성과 청소년의 음주기회가 늘어나게 되었고 음 주를 시작하는 연령도 낮아지고 있는 실정이다. 특히 어린 나이에 시작된 음주는 음주에 대한 의존을 증가시키며 이러한 효과는 여성 에게서 더욱 크다고 알려져 있다.

우리나라 음주인구 중 전체 주류 소비량에서 특히 여성과 청소 년에서 음주율 증가를 보이고 있음에도 불구하고 음주의 심각성 파 악에 관한 필요한 연구마저 미흡하다.

알코올의 약리적, 신체적 영향은 인체의 거의 모든 장기에 영향 을 미친다. 과도한 음주는 구강암, 직장암, 간암 등 여러 가지 암의 발생빈도를 높일 뿐만 아니라 이외에도 심각한 개인 및 사회적 문 제를 초래하고 있는 것으로 알려져 있다(Bagnardi et al., 2001). 알
코올은 소화기계, 중추신경계, 심혈관계, 비뇨기계, 태아, 말초신경, 골격계 등에 영향을 미치는 것으로 알려지고 있다(Alberti et al., 1991). 허혈성 뇌졸중(brain ischemia), 파킨슨씨병(Parkinson's disease), 알츠하이머(Alzheimer's disease), 간질(seizurs), 근위 축성 측삭경화증(amyotrophic lateral scleosis) 등은 뇌의 신경세 포가 선택적으로 죽어가는 만성 신경퇴행성 질환이며, 이들 신경세 포의 손실에 세포자멸사(apoptosis)가 궁극적인 원인이 된다고 보 고되었다(Hunot et al., 1997).

글루탐산(glutamate)은 뇌의 중추 신경계에 존재하는 신경세 포들에 작용하는 대표적인 흥분성 신경전달 물질(excitatory neurotransmitter)이다. 글루탐산은 흥분성 신경전달 기능을 통하 여 기억 및 학습 등의 신경세포의 가소성(neuronal plasticity)과 세포사멸에 관여한다. 글루탐산에 의한 신경세포독성은 대체적으 로 NMDA (N-methyl-D-aspartic acid) 수용체의 비정상적인 활 성화에 기인된다고 여겨지고 있다. 글루탐산 수용체는 일종의 칼슘 
이온 채널이며, 글루탐산 수용체에 의해 유도되는 신경세포의 사멸 현상은 글루탐산 수용체를 통하여 비정상적으로 높아진 세포 내 칼 슘이온 농도가 원인이 된다. 글루탐산 수용체가 활성화됨에 따라 세포내 칼슘이온이 증가되면, 여러 단백질들의 기능이 변화될 수 있다(Schwarzschild et al., 1997). 이러한 사실은 뇌세포자멸사와 변성이 이들 단백질과 관련되어 있음을 시사한다.

Neuronal cell adhesiom molecule (NCAM)은 면역글로불린 가계에 속해 있으며(Doherty et al., 1992), 세포표면의 기질이나 수용체(receptor)에 작용하지만, 일반적으로 신경세포 분화와 신 경가지돌기, 신경가지에 포함되어 있다고 알려져 있다(Amoureux et al., 2000). NCAM은 대부분의 신경세포 생존을 조절하며, 신경 세포자멸사를 억제시키는 기능을 한다(Azizeh et al., 1998). 에탄 올이 세포부착능을 감소시킬 것이라는 보고와 함께(Charles et al., 2001) 신경세포는 생존하거나, 최종적인 장소로 이주하기 위해서 는 성장, 성숙하는 동안 세포와 세포가 접촉되어야 한다. 특별히 $\mathrm{NCAM}$ 이라고 하는 L1 단백질의 결핍은 사람 뇌에서 발달지연이나 소뇌의 비정상적인 발달, 뇌량의 소실 등 비정상 뇌 발달을 야기할 수 있으며, 이러한 비정상 뇌는 태아알코올증후군(fetal alcohol syndrome) 환자에서도 비슷하게 발견된다고 보고되었으며 (Ramanmuthan et al., 1996), 이것은 알코올이 세포부착을 감소 시킨다는 것을 의미하며, 이런 결과는 조직배양실험에서 증명되었 다(Wilkemey et al., 2000).

본 연구에서는 호르몬의 영향을 최소화하기 위하여 미성숙 생쥐 를 이용하여 한국인들이 일반적으로 섭취하는 맥주와 소주에 함유 되어있는 에탄올 농도를 $4 \%, 20 \%$ 로 하여 장 - 단 기간 복강 주사함 으로써 생쥐 뇌 신경세포의 세포자멸사 및 조직학적변화를 유발 하여, 세포자멸사를 관찰할 수 있는 방법인 TUNEL (terminal deoxynucleotidyl transferase mediated dUTP-biotin nick and labeling)과 글루탐산 수용체(glutamate receptor), 그리고 신경 세포에 발현되는 neuronal cell adhesion molecule (NCAM)의 발 현 변화의 증 - 감 여부, 에탄올의 장 - 단 기간 투여가 뇌세포의 감 소 및 대량손실의 원인이 세포자멸사인지, 또는 뇌세포의 변성인 지, 그리고 알코올 농도 및 시간과의 관계가 체중에 어떤 영향을 미 치는지를 조사하고자 하였다.

\section{재료 및 방법}

\section{1. 실험동물 및 재료}

생후 3주된 ICR (Institute of Cancer Research)암컷 생쥐((주) 오리엔트바이오)를 동일한 표준사료로 사육한 후 실험에 사용하였 고, 사료는 삼양유지사료주식회사의 실험동물 사료를 먹게 하였
다. 사육은 $14 / 10 \mathrm{hrs}$ (light/dark)의 조명조건에서, 먹이와 물을 상 시 먹을 수 있도록 충분히 공급해 주었으며, 1 주일 이상 적응시킨 후 실험에 사용하였다.

에탄올 용액은 Sigma $($ (St.Louis,MO,USA)제품을 사용하였 고, $4 \%, 20 \%$, 대조군의 희석용액(pH 0.85)은 생리식염수(중외제 약)를 사용하였다.

Tip과 $1 \mathrm{~mL}$ disposable syringe 등은 일회용품을 사용하였으 며, 실험에 사용된 모든 초자기구와 해부용 가위와 핀셋 등은 $121^{\circ} \mathrm{C}$ 에서 30 분간 고압증기멸균한 뒤 사용하였다.

\section{2. 실험계획 및 실험방법}

실험동물은 3 주 동안 동일한 조건으로 사육한 $18 \sim 20 \mathrm{~g}$ 되는 미 성숙 ICR 암컷 생쥐를 각 군당 5 마리로 하여 15 개 군으로 나누었다 (Fig. 1).

2007년 3월 2일 오후 6시부터 3월 30일 까지 한양대학교 동물 실험실에서 대조군(총 5개 군)과 농도 당 시간 별, 농도 당 기간 별로 normal saline 주사군, $4 \%$ 에탄올 주사군, $20 \%$ 에탄올 주사군 으로 나누어 체중 $\mathrm{kg}$ 당 $2 \mathrm{~g}$ 의 조제된 에탄올을 같은 시간에 복강 주사하 여 6시간, 24시간에 도살 군(총 9개 군)과 1주, 4주 동안 매일 같은 시간에 복강 주사한 군(총 6개 군)으로 나누었다.

실내온도 $25^{\circ} \mathrm{C}$, 상대습도 $50 \sim 60 \%$ 인 항온항습 조건에서 실험 군은 배부에 둥근 면봉을 사용하여 70\% 소독용 알코올로 약 2 3 회 도포 후 준비된 시약을 희석 에탄올을 복강 주사 하였으며, 경추 탈골법을 이용하여 도살하였다.

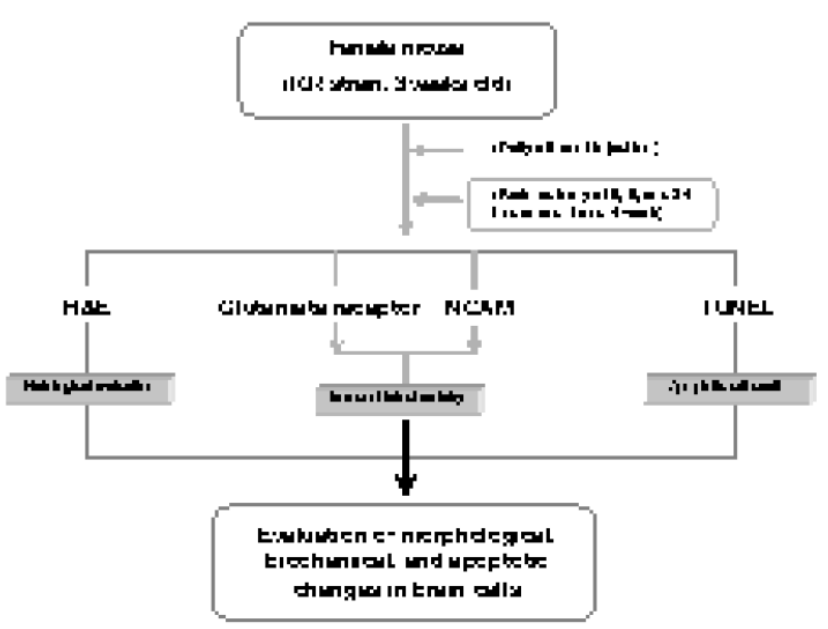

Fig. 1. Flow-sheet of the present experiments for the morphological and immunohistochemical evaluations of the ethanol effects on mouse brain. Abbreviation are explained as followed. H\&E, hematoxylin and eosin; NCAM, neuronal cell adhesion molecule; TUNEL, terminal deoxynucleotidyl transferase-mediated dUTPdioxygenin nick end - labeling. 


\section{1) 조직채취 및 표본제작}

각 군의 해당 시기에 경추 탈골법으로 도살한 후 두부를 절개하 여 해부현미경 하에서 생쥐 뇌를 적출 하였다. 채취한 조직은 일반 조직화학 염색과 면역조직화학 염색을 위해 10\% 중성 formalin 고 정용액(10\% neutral buffered formalin ; NBF) 용액에 고정(1일 1 회 새로운 $10 \% \mathrm{NBF}$ 용액으로 바꾸어서 3일간 고정) 하였다.

고정이 끝난 조직은 고정액을 제거하기 위하여 1 시간 동안 흐르 는 물에 세척한 후 저 농도에서 고농도 알코올 과정을 거쳐 탈수하 였다. 크실렌으로 알코올을 제거한 후 조직을 투명화 하여 파라핀 을 침투시켜 포매하였다. 조직의 이탈을 방지하기 위하여 슬라이드 에 poly-L-lysine을 도말하고 건조시켰다. 절편 박절기(Microtome, Microm)를 사용하여 $4 \mu \mathrm{m}$ 로 박절한 후 슬라이드를 크실렌에 넣어 파라핀을 제거한 후 알코올 과정을 거쳐 물에 세척하였다.

\section{2) 일반 조직학적 검사}

본 실험에 사용된 모든 시약은 별도의 표시가 없는 경우, Sigma $\mathbb{R}$ (St.Louis,MO,USA)사의 제품을 사용하였다.

(1) Hematoxylin-Eosin (H\&E) 염색

미성숙 생쥐 뇌세포의 핵과 세포질을 관찰하기 위하여 헤마톡실 린과 에오신에 5 분 동안 염색한 후, $1 \% \mathrm{HCl}$-alcohol에 탈색시키 고, $1 \%$ Ammonia Water에 청색화 과정을 거친 후 흐르는 물에 10 분 동안 방치하였다. 그 후 에오신으로 2 분간 세포질을 염색한 후 알코올 과정을 거쳐 탈수시켰으며, 크실렌에서 투명시킨 후 Canada balsam으로 봉입하여 영구표본을 제작하였다.

\section{3) TUNEL 염색}

미성숙 생쥐 뇌세포에서 세포자멸사를 관찰하기 위하여 생리식 염수로 5 분간 처리하고 $\mathrm{PBS}$ 로 세척한 후 $4 \%$ 메탄올 고정액을 조직 슬라이드에 점적하고 실온에서 15 분간 정치한 다음 다시 PBS로 5 분씩 2번 세척하였다. 그 후 조직 내의 단백질을 제거하기 위하여 슬라이드의 조직표본을 proteinase $\mathrm{K}(0.2 \mu \mathrm{g} / \mathrm{mL})$ 로 실온에서 10 분 동안 처리하고 PBS로 세척하였다. 이어서 DeadEnd ${ }^{\mathrm{TM}}$ Fluorometric TUNEL System Kit (Promega Co, Madison, WI, USA)를 이용하 여 TUNEL (terminal deoxynucleotidyl transferase-mediated dUTP-biotin nick and labeling) 염색을 시행하였고, 그 후 0.1 $\mu \mathrm{g} / \mathrm{ml}$ propidium iodide (PI; Sigma chemical Co, St. Louis, $\mathrm{MO}, \mathrm{USA}$ )로 15 분간 상온 암실에서 배경 염색을 시행하여 발색을 유도시킨 다음 glycerin gelly로 봉입한 후 즉시 통상적 형광현미경 (fluorescence microscope)으로 검경하여 조직에서 세포핵의 응 축, 분절화 또는 세포자멸사 소체의 소견이 녹색 형광으로 관찰되
면 이를 세포자멸사 양성의 소견으로 판정하였다.

4) 면역조직화학 염색

(1) 글루탐산 수용체(glutamate receptor) 염색

알코올에 유발된 생쥐 뇌세포의 글루탐산 수용체의 변화를 관찰 하기 위하여 표본을 $3 \% \mathrm{H}_{2} \mathrm{O}_{2}$ 로 10 분간 처리하여 내인성 효소를 제 거한 후 세척하였다. 항원부활을 위하여 $10 \mathrm{mM}$ citric acid buffer $\mathrm{pH6.0}$ 용액을 사용하여 $121^{\circ} \mathrm{C} 10$ 분간 고압멸균 하였다. Tris buffer ( $\mathrm{pH}$ 7.6)에서 5 분간 방치시키고 DW에서 5 분 동안 2 회 세척 하였다. Tris buffer에 5 분 동안 세척한 후 비 특이적 반응을 제거하 기 위해 $5 \%$ normal goat serum을 20 분간 조직 slide에 점적 하였 다. 여기에 1차 항체인 rabbit anti-glutamate receptor (LAB VISION, Co, USA)를 1:100으로 희석하여 1시간 동안 반응시켰다. 그후, Tris buffer로 5분씩 3회 세척하고, link antibody에 biotin이 부착된 goat anti-rabbit IgG (Vector Labratories, Burlingame, $\mathrm{CA}, \mathrm{USA}$ 로 20 분 동안 반응 시켰다. 반응을 시킨 다음, Tris buffer 로 5분씩 3회 세척 하였다. peroxidase가 결합된 streptavidin (DAKO, Carpinteria, CA, USA)에 20분 동안 반응시켰다.

반응이 끝난 후 slide를 Tris buffer에 세척한 다음, 발색제인 3, 3'-diaminobenzidine tetrahydrochloride (DAB) (DAKO, Carpinteria, CA, USA)으로 5분 동안 정색반응을 시켰다. 발색이 끝난 후 slide를 DW에 2분씩 3회 세척하고 마지막으로 Mayer's hematoxylin에 10초간 대조염색한 후, Canada balsam으로 봉입 하고 광학현미경으로 관찰하였다.

(2) 신경세포 부착단백질 L1 (NCAM) 염색

생쥐 뇌세포에서 신경세포의 부착능을 관찰하기 위하여 면역조 직화학 방법을 이용하여 파라핀이 제거된 슬라이드를 $3 \% \mathrm{H}_{2} \mathrm{O}_{2}$ 로 10 분간 처리하여 내인성 효소를 제거한 후 세척하였다. 항원부활 을 위하여 $10 \mathrm{mM}$ citric acid buffer pH6.0 용액을 사용하여 $121^{\circ} \mathrm{C} 10$ 분간 고압멸균 하였다. Tris buffer $(\mathrm{pH}$ 7.6)에서 5 분간 방치시키고 DW로 5 분 동안 2 회 세척하였다. Tris buffer에 5 분 동 안 세척한 후 비 특이적 반응을 제거하기 위해 5\% normal goat serum을 20 분간 조직 슬라이드에 점적 하였다. 여기에 1 차 항체인 monoclonal mouse anti-L1 (BD Pharmingen, San Diego, CA, $\mathrm{USA})$ 을 $1: 100$ 으로 희석하여 1 시간 동안 반응시켰다. 그 후, Tris buffer로 5분씩 3회 세척하고, link antibody에 biotin이 부착된 goat anti-mouse IgG (Vector Labratories, Burlingame, CA, USA)로 20분 동안 반응 시켰다. 반응을 시킨 다음, Tris buffer로 5 분씩 3회 세척 하였다. Peroxidase가 결합된 streptavidin (DAKO, Carpinteria, CA, USA)에 20분 동안 반응시켰다. 
반응이 끝난 후 slide를 Tris buffer에 세척한 다음, 발색제인 $\mathrm{DAB}$ 으로 5 분 동안 발색을 시켰다. 발색이 끝난 후 slide를 DW에 2 분씩 3회 세척하고 Mayer's hematoxylin에 10초간 대조염색한 후, Canada balsam으로 봉입하고 광학현미경으로 관찰하였다.

대조군과 에탄올 투여 군의 생쥐 몸무게를 알아보기 위하여 체 중을 측정하였고, 통계적 유의성은 Student's t-test를 사용하여 실 시하였으며, 유의수준은 0.05 미만으로 설정하였다.

\section{결 과}

\section{1. 체중변화}

에탄올 농도와 성장기간에 따른 생쥐의 몸무게 변화를 보면 Table 1 에서 보는 바와 같이 1주후 대조군의 몸무게 $(\mathrm{g})$ 는 $21.18 \pm 0.51,4 \%$ 에탄올 투여군 몸무게는 $19.9 \mathrm{~g} \pm 0.97,20 \%$ 에탄 올 투여군의 몸무게는 $19.04 \mathrm{~g} \pm 1.51$ 을 나타내었으며, 4주후 대조 군의 몸무게는 $27.58 \pm 1.15,4 \%$ 에탄올 투여군은 $25.24 \mathrm{~g} \pm 1.20$, $20 \%$ 에탄올 투여군은 $24.02 \mathrm{~g} \pm 0.63$ 을 나타내었다.

1 주에서 $4 \%$ 에탄올 투여군은 대조군과 비교하여 평균이 $1.28 \mathrm{~g}$ 차이가 나며, $20 \%$ 에탄올 투여군은 $2.14 \mathrm{~g}$ 차이가 발생하였고, 4 주 에서 $4 \%$ 에탄올 투여군은 대조군과 비교하여 평균이 $2.34 \mathrm{~g}$ 차이가 나며, $20 \%$ 에탄올 투여군과는 $3.56 \mathrm{~g}$ 차이가 발생하였으며, 이를

Table 1. The changes of the body weight after the treatment of the various concentrations of ethanol. Ethanol $(2.5 \mathrm{~g} / \mathrm{kg}, 4 \%$ or $20 \%$ in saline) was intraperitoneally injected to 3 -week-old immature mice at for 1 and 4 weeks. Data are mean \pm SD $(n=5)$

\begin{tabular}{lccc}
\hline Week & & & \\
\hline No. & Control & 4\% ethanol & $20 \%$ ethanol \\
\hline 1 & $21.4 \mathrm{~g}$ & $20.1 \mathrm{~g}$ & $21.2 \mathrm{~g}$ \\
2 & $21.4 \mathrm{~g}$ & $20.2 \mathrm{~g}$ & $19.3 \mathrm{~g}$ \\
3 & $21.6 \mathrm{~g}$ & $18.2 \mathrm{~g}$ & $17.2 \mathrm{~g}$ \\
4 & $21.2 \mathrm{~g}$ & $20.6 \mathrm{~g}$ & $18.1 \mathrm{~g}$ \\
5 & $20.3 \mathrm{~g}$ & $9.9 \mathrm{~g}$ & 1 \\
mean & $21.18 \mathrm{~g}$ & $19.9 \mathrm{~g}$ & 19.04 \\
SD & 0.51 & 0.97 & 1.51 \\
t-test & & 0.09 & 0.05 \\
\hline
\end{tabular}

\begin{tabular}{lccc}
\hline Week & \multicolumn{3}{c}{} \\
\hline No. & Control & 4\% ethanol & 20\% ethanol \\
\hline 1 & $27.5 \mathrm{~g}$ & $24.8 \mathrm{~g}$ & $24.1 \mathrm{~g}$ \\
2 & $26.2 \mathrm{~g}$ & $24.3 \mathrm{~g}$ & $23.8 \mathrm{~g}$ \\
3 & $28.1 \mathrm{~g}$ & $24.1 \mathrm{~g}$ & $24.3 \mathrm{~g}$ \\
4 & $29.2 \mathrm{~g}$ & $26.8 \mathrm{~g}$ & $23.1 \mathrm{~g}$ \\
5 & $26.9 \mathrm{~g}$ & $26.2 \mathrm{~g}$ & $24.8 \mathrm{~g}$ \\
mean & $27.58 \mathrm{~g}$ & $25.24 \mathrm{~g}$ & $24.02 \mathrm{~g}$ \\
SD & 1.15 & 1.20 & 0.63 \\
t-test & 0.01 & 0.01 & \\
\hline
\end{tabular}

통하여 1 주에는 각 군당의 몸무게 차이가 없었으나, 4주에는 대조 군과 $4 \%$ 와 $20 \%$ 에탄올 투여 군의 몸무게가 대조군에 비하여 2.34 $\mathrm{g}, 3.56 \mathrm{~g}$ 감소한 것으로 나타났으며, $\mathrm{t}$-값은 각각 0.01 로서 대조군 과의 유의성이 있었다(Table 1).

\section{2. 조직학적 염색 결과}

뇌의 일반적인 형태인 핵과 세포질을 보기위하여 H-E 염색을 실 시하였다. 대뇌의 회색질과 백질을 구별 할 수 있었고 회색질에서 신경세포(신경원), 신경세포돌기 구분 할 수 있었다. 대뇌 겉질 분 자층에서 약간의 수평세포와 마르티노티세포의 축삭과 pyramidal cell, 방추세포의 가지돌기를 포함하는 많은 신경섬유를 관찰 할 수 있었다. Small pyramidal cell의 소실, 잔존하는 신경원의 종창, 핵 응축, 색소성 위축 등 알코올 농도와 시간별 변화는 대뇌에서 뚜렷 하게 구분 할 수는 없었다(Fig. 2A).

부챗살층, 피라미드층, 뭇모양층, 해마 형성체를 관찰하였다 (Fig. 2B). 해마형성체에 존재하는 세포의 변화는 알코올농도, 시간 에 변화가 없었다. 소뇌의 피질은 회색질로 분자층, 조롱박 신경원, 과립층이 관찰 되었으며 특히 과립층은 헤마톡실린에 강하게 염색 된 과립세포들이 조밀하게 염색 되었다. 분자층은 에오진에 약하게 염색되었으며 별신경세포, basket cell가 관찰되었다. 세포질은 호 염기성에 강하게 염색되었다. 세포가 더욱더 성장하거나 분화될수 록 에오진에 강한 세포질을 볼 수 있었다(Fig. $2 \mathrm{C}$ ). 분자층과 과립층 에는 작은 신경세포들이 존재함을 관찰할 수 있었다. 핵에 비하여 세포질이 적어 임파구와 비슷하게 핵만 염색되어 나타났다. 과립층 과 분자층사이에 purkinje신경원들이 일렬로 배열된 것을 관찰 할
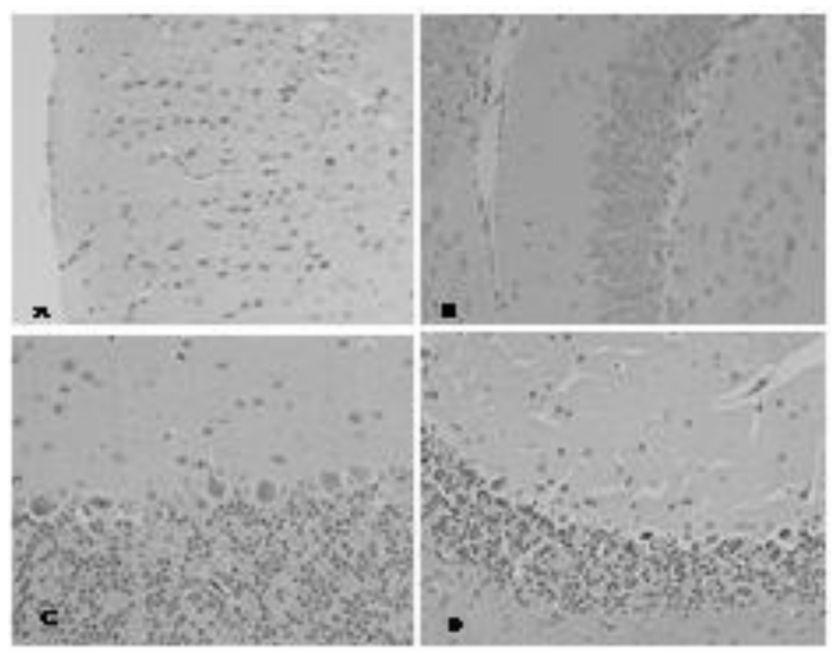

Fig. 2. Light microphotographs of the mouse brain after the treatment of ethanol. Magnification, $\times 400$. (A) Control of cerebral cortex. (B) Hippocampus with 4\% ethanol. (C) Cerebellar at 1 week with $4 \%$ ethanol treatment. (D) Cerebellar at 4 weeks with $20 \%$ ethanol treatment. 
수 있었고, 이 세포에 가지 돌기가 나타남을 확인 할 수 있었다(Fig. 2D).

\section{TUNEL 염색 결과}

알코올 투여 후 형광현미경(Olympus BX51, FITC filter) 관찰 결과 6시간 후에 TUNEL 염색결과 대뇌에서 세포자멸사 소체가 TUNEL에 양성 결과(arrow)를 나타내었으나 대량적인 세포자멸 사 소체는 발견되지 않았고(Fig. 3A), 해마형성체나, 소뇌 등에서도 거의 발견되지 않았으며 24 시간 군에서는 많은 수의 뇌신경세포들 이 TUNEL 양성결과를 나타냈다(Fig. 3B). 양성 부위는 대뇌 혈관 분포지역에 국한되어 나타났으며 소뇌의 과립층이나 분자층에는 거의 나타나지 않았으며(Fig. 3D), 소뇌에서 purkinje cell은 양성 결과가 나타나지 않았다. TUNEL 염색 상 세포자멸사에 민감한 희 소돌기세포나 microglial cell는 뇌세포가 PI 배경염색에 빨강색으 로 염색되어 구분 할 수가 없었다. 알코올 투여 후 1 주 군에서는 6 시 간 군과 비슷한 결과를 나타냈으며 소뇌의 분자층에서 극히 드물게 나타났으며 4주 군에서도 비슷한 결과가 나타났다.

\section{4. 면역조직화학 염색 결과}

1) 글루탐산 수용체(glutamate receptor) 염색 결과

신경세포체들이 분포되어 있는 대뇌피질에서 글루탐산 수용체 의 발현은 약하게 나타났고 작은 삼각형 모양의 신경세포들이 존재 하는 과립 모양 신경원들의 염색은 좀 더 강하게 나타났다. 위축되 거나 변성으로 보이는 pyramidal cell에서는 수용체의 염색성이
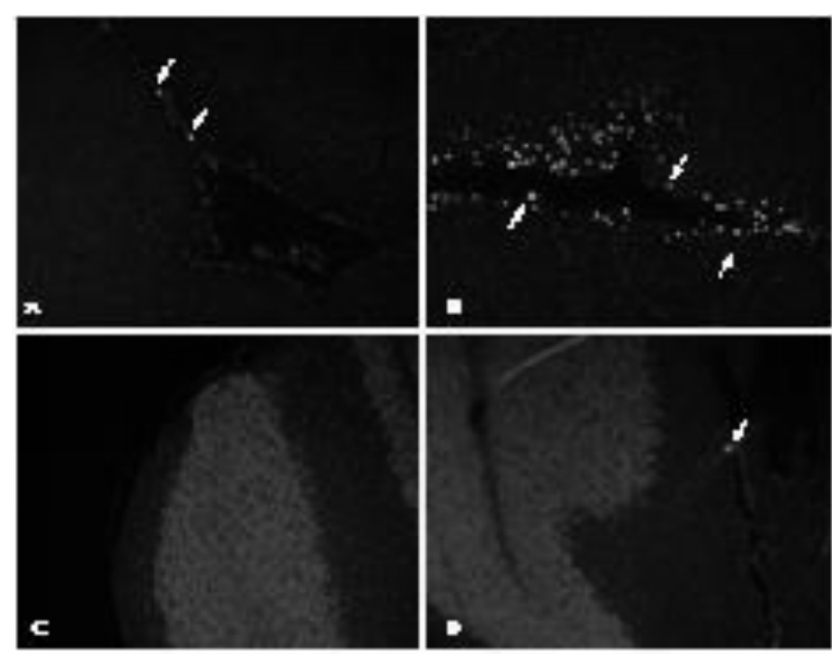

Fig. 3. Apoptosis of the brain cells after the alcohol treatments was assessed by in situ TUNEL analysis. Apoptotic cells were indicated with arrows. Magnification, $\times 200$. (A) Cerebral cortex at 6 hours with $20 \%$ ethanol treatment. (B) Cerebral cortex at 24 hours with $20 \%$ ethanol treatment. (C) Cerebella at 1 week with $20 \%$ ethanol treatment. (D) Cerebella at 4 weeks with $20 \%$ ethanol treatment.
강하게 나타났다. 큰 피라밋 신경원이 존재하는 바깥 피라미드층 및 신경층에는 다양한 크기의 신경원이 존재하는 부위로 수용체의 발현은 매우 미약하게 나타났다. 특히 거대 피라밋 신경원이 존재 하는 속피라미드 층에서 세포질에 강한 염색성을 나타내었다 (arrow). 대뇌에서 글루탐산 수용체 염색결과는 대조군이나 실험 군 모두 비슷한 결과를 나타냈다. 그러나 소뇌의 과립세포에는 발 현되지 않았고 과립층과 분자층에서 격리된 purkinje cell 에는 더 욱 강하게 나타났다. 특히 대조군에서 purkinje cell 이 더욱 분화할 수록(Fig. 4A, 4B) 강한 염색 결과를 나타내었다. 그러나 알코올 투 여 농도가 높고 장기간 투여된 군 일수록 핵이 응축되거나 위축된 염색성은 나타나지 않았다. 분자층에 있는 astrocyte 에는 약한 염 색성을 나타내었다(Fig. 4C, 4D).

\section{2) 신경세포 부착단백질 L1 (NCAM) 염색 결과}

신경세포 부착단백질의 일종인 L1 은 크고 작은 신경세포 들이 주로 존재하는 회색질에서 신경세포들의 염색성이 다양하게 나타 났으며 주로 신경아교세포들로 구성된 백색질에는 L1 염색성이 나 타나지 않았다. 염색결과 성장이 활발한 신경세포에서 강하게 발현 되었고 위축이나 퇴행 등으로 보이는 신경세포에서 발현은 세포질 에 약하게 나타났다. 신경세포체의 크기가 큰 속피라밋층의 가지돌 기를 가진 거대 신경세포들의 세포질에 강하게 염색되었다(arrow). 대뇌피질에서의 L1 염색의 경우, 시간이나 알코올농도 투여에 따 른 염색성의 변화는 매우 차이가 없었다. 소뇌에서의 염색결과 헤 마톡실린에 엷게 염색되는 분자층 내의 별신경원세포, basket cell
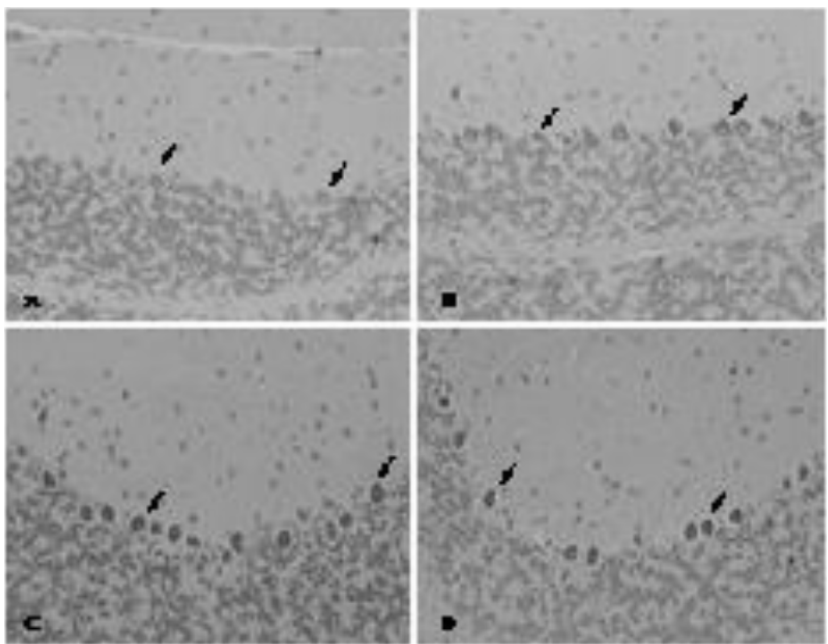

Fig. 4. Immunohistochemistry for glutarmate receptor after the treatment of the various concentration of ethanol in mice. Brown colored cells (arrows) represent glutamate receptor positive prukinje cells. Magnification, $\times 400$. (A) Control. (B) Cerebellar at 1 week with $4 \%$ ethanol treatment. (C) Cerebellar at 4 week with $4 \%$ ethanol treatment. (D) Cerebellar at 4 week with $20 \%$ ethanol treatment. 


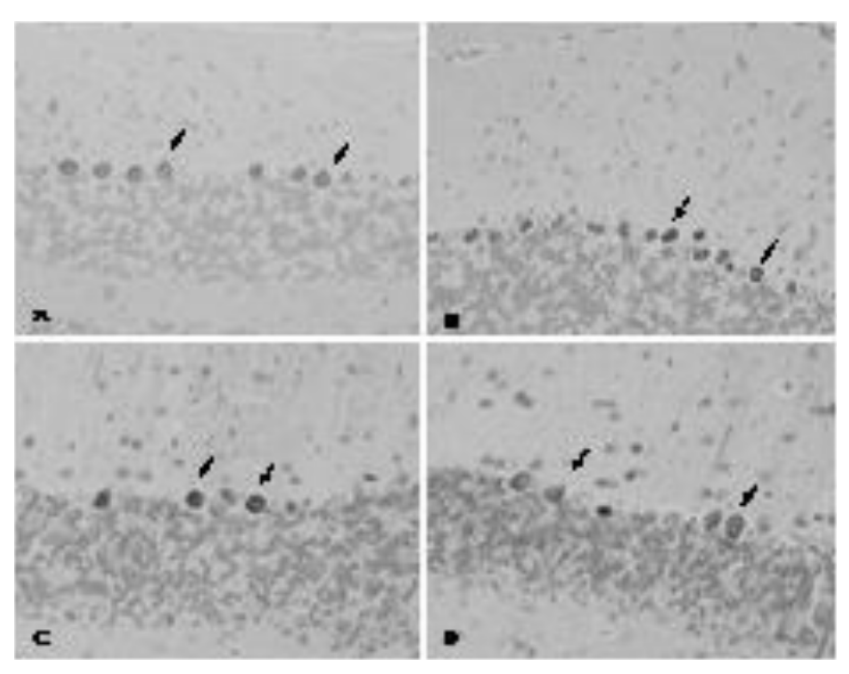

Fig. 5. Immunohistochemistry for $\mathrm{L} 1$ after ethanol treatment in mouse brain. Brown colored cells (arrows) represent L1 positive prukinje cells. Magnification, $\times 400$. (A) Control. (B) Cerebellar at 1 week with $4 \%$ ethanol treatment. (C) Cerebellar at 4 week with $4 \%$ ethanol treatment. (D) Cerebellar at 4 week with $20 \%$ ethanol treatment.

염색성은 나타나지 않았고, 조롱박신경원층의 일렬로 배열된 핵소 체가 뚜렷하고 핵이 분명한 purkinje cell에 강하게 염색되었고 (Fig. 5A, 5B), 이 세포의 주가지 돌기에도 강하게 염색되었다. 세포 질의 응축이나, 위축된 핵, 핵소체 소실, purkinje cell에서는 L1의 염색성이 나타나지 않았다. 알코올 투여 농도가 높고 장기간 투여 된 군 일수록 L1 염색성은 미약하거나 대조군에 비하여 감소하였다 (Fig. 5C, 5D).

\section{고 찰}

여성과 청소년의 음주기회가 늘어나면서 음주를 시작하는 연령 도 낮아지고 이는 음주에 대한 의존도로 더욱 발전할 가능성이 있 다. 우리나라 주류 소비량은 매년 비슷한 평균을 보이지만, 여성과 청소년에서의 음주율이 증가되고 있음에도 불구하고 음주의 심각 성 파악에 관한 필요한 연구는 미흡하다. 음주로 인해 야기되는 알 코올의 약리적, 신체적 영향은 인체의 거의 모든 장기에 영향을 미 칠 뿐만 아니라 개인 및 사회에 심각한 문제를 초래하고 있는 것으 로 알려져 있다(Bagnardi et al., 2001).

뇌의 신경세포가 선택적으로 죽어가는 것은 만성 신경퇴행성 질 환이며, 이들 신경세포의 손실에 세포자멸사(apoptosis)가 궁극적 인 원인이 된다고 보고되었다. 세포사멸에는 세포자멸사와 괴사가 있다. 이들의 형태적 변화는 서로 다른 양상을 나타내며, 세포자멸 사(apoptosis)는 여러 가지 생리적 자극으로 일어나는데 사멸과정 중의 세포는 크기가작아진다(Savill et al., 1990). 세포자멸사는 괴
사세포에 반하여 크기가 작아지고 주위 세포로부터 떨어져 나오며 주위 세포에 유출되지 않아 염증반응을 일으키지 않는데 이것이 괴 사와의 큰 차이점 중 하나이며, 세포사이 결합이나 세포-기질 결합 에 이상을 초래할 수 있다(Puviani et al., 2003). 세포자멸사는 후 기에 나타나는 DNA 분절화나 핵 분절화는 세포자멸사에 필수적이 지만(Ankarcoma et al., 1995), 글루탐산에 유발된 흥분독성 세포 자멸사는 형태적 변화가 미미하여 종종 비-세포자멸사로서 묘사된 다(Macmanus et al., 1997). 세포자멸사를 확인하는 가장신뢰성 있는 방법 중의 하나가 DNA분절화 현상에 의한 TUNEL 염색방법 인데, 특히 이것은 파라핀 절편 조직에서 각광을 받고 있다.

이전의 많은 연구들은 설치류나 사람에게서 에탄올이 세포자멸 사에 의해 뇌세포 발달을 방해한다고 보고하였으며(Dikranian et al., 2001), 특히 에탄올 투여 후 24시간 후에 대뇌의 피질층 II에서 TUNEL 염색이 강하게 발현되었다고 보고되어, 본 실험결과와 같 은 결과를 나타내었다. 그러나 시간이 1 주, 4 주 등 시간이 긴 군 일 수록 TUNEL 염색성은 미비하거나 나타나질 않아 뇌 발달 이전과 이후의 세포사멸에 차이가 나타남을 확인할 수 있었다.

컴퓨터 단층촬영을 통해 만성알코올 중독자의 뇌 변성이나 위 축, 뇌실의 확대가 확인되었다(Harper et al., 1987). 알코올환자의 뇌 피질에서 다양한 조직학적 변화 즉 pyramidal cell의 손실과 잔 존하는 신경원의 종창, 핵 농축과 색소성위축등이 있으나 이는 모 두 비 특이적이다. 특히 소뇌의 상부 충부와 이에 인접한 뇌의 상부 표면에 위축과 변성이 뒤따른다고 보고되었다(Melgaard et al., 1986).

본 연구 결과 에탄올 투여 후 6시간, 24 시간, 1 주일에서는 대뇌 와 소뇌의 위축 등 뚜렷한 변화는 관찰할 수 없었는데, 4 주간의 장 기간 투여 시 purkinje cell의 대량 소실이 소뇌의 위축이나 변성을 초래할 수 있다고 사료된다(Fig. 2). 중추신경세포들은 대사성 손상 을 비롯한 여러 종류의 물리-화학적 손상에 특히 민감하다고 보고 되었다. 단지 수 분간의 허혈(ischemia)만으로 중추신경세포는 종 종 비가역적손상에 대한 민감성은 글루탐산수용체의 과다한 흥분 에 의해 비가역적 손상이 초래된 것이라 보고하였고(Choi et al., 1987), 에탄올이 뇌 발달 시기동안 글루탐산수용체의 수적 감소 및 기능을 감퇴시킬 수 있다고 보고 되었다(Costa et al., 2000). 본 연 구 결과 에탄올을 투여하지 않은 글루탐산 수용체 염색결과, 대조 군에서는 purkinje cell에 일정하게 염색되었으나, 실험 군에서는 염색된 세포의 수적감소 및 발현감소가 확연히 나타났으며(Fig. 4), 이런 수적 감소, 발현감소가 결국 세포의 기능을 감소시키고, 이는 수많은 신경전달계에 영향을 미쳐 이상을 초래할 것이라 판단된다.

$\mathrm{NCAM}$ 은 신경세포부착단백질로써 신경세포줄기(exon)의 성 장과 분화, 신경세포의 세포자멸사 억제에 관여한다고 보고되었다 
(Skaper et al., 2001). NCAM 염색결과 알코올투여가 길고 농도가 높은 군 일수록 $\mathrm{NCAM}$ 의 발현이 매우 약하거나 없었다. 세포가 생 존, 발달, 이주하기 위해서는 세포와 세포가 접촉되어 이웃세포에 게 신호전달 등 여러 가지 기능을 수행해야 하는데, 세포 부착능의 결여는 신호전달의 감소로 세포의 이상을 초례한다고 판단된다. 조 직배양 실험에서 알코올이 세포부착능을 저해한다고 보고하였고 (Wilkemeyer et al., 2000), 본 실험에서도 알코올이 신경세포의 부착능을 감소시킨다는 것을 확인할 수 있어 생체 내 실험과 생체 외 실험이 비슷한 결과를 나타내었다(Fig. 5).

기존에 알코올을 이용한 많은 실험들이 뇌의 신경세포를 대상으 로 이루어졌으나(Stressguth et al., 2000), 많은 연구들은 주로 뇌 발달 이 완성되기 전 즉, 설치류에서 신경세포 접합부위가 형성되 는 기간인 생후 1 주일 이내에 이루어졌고 에탄올이 신경세포의 사 멸을 유발하여 신경병리 이상을 일으킨다고 보고하였다(Olney et al., 2004). 그러나 뇌세포 발달이 이루어지고 성장이 이루어진 3주 이후의 설치류에 에탄올 투여 후 신경세포의 조직학적변화를 알아 보기 위한 연구는 매우 미흡한 실정이며, 특히 사람에게 청소년기 의 음주에 대한 신경세포의 변화 및 알코올독성에 대한 실험결여, 홍보 및 교육 등이 미비한 실정이다. 또한 알코올 섭취 후간손상 및 지방간 발생을 억제 하는 물질에 대한 연구가 수행 되고는 있으나, 향후 좀 더 많은 연구가 필요하다(Lee et al., 2014).

본 연구는 호르몬 영향을 최소화 시킬 수 있는 미성숙 생쥐를 대 상으로 알코올 농도 및 시간 등의 실험기준을 마련하여 향후 인체 에 유용한 자료를 제공하는 실험의 기초가 되고자 했다. 뇌세포독 성에 대한 자세한 기전을 밝히기 위해서는 어떤 전사나 발현에 관 계되는 세포내 2차 전달단백질인 $\mathrm{ca}^{2+}$ 채널과 관련된 수용체 및 $\mathrm{G}$ protein 같은 다양한 분야에서 연구가 동시에 수행되어져야 할 것 이라 생각된다.

본 연구의 결과를 기초로 하여 이러한 여러 사항들을 고려하여 알맞은 실험방법을 선택해야 할 것이며 무엇보다도 에탄올을 이용 한 실험에 대한 명확한 기준이 필요하다. 향후 사멸과 변성에 대한 분자적 기전에 대한 더 많은 연구가 진행되어져야 할 것이다.

\section{Acknowledgements: None}

Funding: None

Conflict of interest: None

\section{References}

1. Alberti KG. A coordinated approach to treat chronic disorders. World Health Forum 1991, 12(3):285-8.

2. Amoureux MC, Cummingham BA, Edelman GM, Crossin KL.
N-CAM binding inhibits the proliferation of hippocampal progenitor cells and promotes their differentiation to a neuronal phenotype. J Neurosci 2000, 20:3631-3640.

3. Ankarcrma M, Dypbukt JM, Bonfoco E, Zhivotovsky B, Orrenius S, Lipton SA, Nicotera P. Glutamate-induced neuronal death: a sucession of necrosis of apoptosis depending on mitochondrial function. Neuron 1995, 15:961-973.

4. Son Gye-Sung. A Study of Clinical Usefulness of Carbohydrate Deficient Transferrin in Patients with Alcoholic Liver Disease. Korean J Clin Lab Sci 2005, 37:8-15

5. Azizeh BY, Cribbs DH, Kreng VM, Cotman CW. Cross-linking of NCAM receptors on neurons induces programmed cell death. Brain Res 1998, 15:796-914.

6. Bagnardi V, Blangiardo M, Vecchia CL, Corrao G. A meta-analysis of alcohol drinking and cancer risk. Br J Cancer 2001, 85:1700-1705.

7. Charles R, Goodlett CR, Horn KH. Mechanisms of alcohol induced damage to the developing nervous system. Alcohol Research and Health 2001, 25(3):175-84.

8. Choi SY, Churchich JE, Zaiden E, Kwok F. Brain pyridoxine-5-phosphate oxidase. Modulation of its catalytic activity by reaction with pyridoxal 5-phosphate and analogs. J Biol Chem 1987, Sep 5;262(25):12013-7.

9. Costa ET, Savage DD, and valezuela CF, A review of the effect of prenaral or early postnatal ethanol exposure on brain ligand-gated ion channels. Alcoholism: Clinical and Experimental Research 2000, 24(5):706-715.

10. Dikranian K, Ishimaru MJ, Tencova T, Babruyere J, Qin YQ. et al. Apotosis in the in vivo mammalian forebrain. Neurobiol Dis 2001, 8: 359-379.

11. Doher P, Walsh FS. Cell adhesion molecules, second mesengers and axonal growth. Curr Opin Neurobiol 1992, 2:595-601.

12. Harper C, Kril J, and Daly J. Are we drinking our neurones away? British Medical Journal 1987, 294:534-6.

13. Hunot S, brugg B, Ricard D, Michel PP, Ruberg M, Faucheux BA, Agrid Y, Hirsch EC Nuclear Translocation of NF-kappaB is increased in dopaminergic neurons of patients with Parkinson disease. Proc Natl Acad Sci USA 1997, 94:7531-7536.

14. Mi-Yea Lee, Won Shik Kim and Yong Lim Effects of Green Tea Catechins (GTC) on the Treatment of Hangover and Prevention of Liver Disease. Korean J Clin Lab Sci. 2014, 46(4):131-135

15. MacManus JP, Rasquinha I, Black MA, Laferriere NB, Monette R, Walker T. Glutamate-treated rat cortical neuronal cultures die in a way different from the classical apoptosis induced by staurosporine. Exp Cell Res 1997, 233:310-320.

16. Melgaard B, Ahlgren P. Ataxia and cerebllar atrophy in chronic alcoholics. Journal of Neurology 1986, 233:13-15.

17. Puviani M, Marconi A, Cozzani E, Pincelli C. Fas ligand in pemphigus sera induces keratinocyte apoptosis through the activation of caspase-8. J Invest Dermatol 2003, 120:164-167.

18. Ramanathan R, Wilkmeyer MF, Mittal B, Perides G, Charness ME. Alcohol inhibits cell-cell adhesion mediated by human L1. Journal of Cell Biology 1996, 133:381-390.

19. Savill J, Dransfield I, Hogg N, Haslett C. Vitronectin receptor-mediated phagocytosis of cells undergoing apoptosis. Nature 1990, 343:170-173.

20. Schwarzschild I, Cole RL, and Hyman SE. Glutamate, but not 
dopamine, stimulates stress-activated protein kinase and AP-1-mediated transcription in striatal neurons. J Neuroscience 1997, 17:3455-3466.

21. Stephen, Skaper D, Moore E, Frank S, Walsh. Cell signaling cascades regulating neural growth-promoting and inhibitory cues. Prog Neurobiol (New York) 2001, 65:593-608.
22. Streissguth AP, O'Malley K. Neuropsychiatric implications and long-term consequences of fetal alcohol spectrum disorders. Semin Clin Neuropsychiatry 2000, 5:177-190.

23. Wilkemyer MF, Sebastian AB, Smith SA, Charness, ME. Antagonists of alcohol inhibition of cell adhesion. Pro Natl Acad SCi USA 2000, 97:3690-3695. 